\title{
Exploring the influence of training and development on employee's performance: Empirical evidence from the Indian tourism industry
}

\author{
Mohd Arwab ${ }^{a *}$, Jamal Abdul Nasir Ansaria, Mohd Azhar ${ }^{\mathrm{a}}$ and Mohd Ashraf Ali ${ }^{\mathrm{a}}$
}

${ }^{a}$ Aligarh Muslim University, India

\begin{tabular}{l}
\hline C H R O N I C L E \\
\hline Article history: \\
Received: October 1, 2021 \\
Received in revised format: \\
October 82021 \\
Accepted: October 25, 2021 \\
Available online: \\
October 25, 2021 \\
\hline Keywords: \\
Training and Development \\
Employee Performance \\
Motivation for Training \\
Benefits from Training \\
Support for Training \\
Contextual Performance \\
Task Performance \\
Adaptive Performance \\
Travel and Tourism \\
\hline
\end{tabular}

\begin{abstract}
A B S T R A C T
The aim of this paper is to explore the influence of training and development on employee's performance through different dimensions. Moreover, this study proposes a model in the area of human resource development to be used for testing and improving the performance of employees in the Indian travel and tourism sector. An integrated model was developed highlighting the relationship between the training and development and employee performance. Using the sample of $146 \mathrm{em}-$ ployees, structural equation modelling (SEM) was employed to validate the hypothesized relationship by evaluating the responses of employees working in the Indian travel agencies. The findings of this study demonstrate a strong relationship between training and development and employee performance in the travel industry and also can be used by managers and HR professionals for organizing exclusive training programs for improving employee's performance based on the dimensions used in this paper. The present study provides an empirical and theoretical explanation of different dimensions associated with training and development and employee performance, especially in the Indian tourism industry.
\end{abstract}

O 2022 by the authors; licensee Growing Science, Canada

\section{Introduction}

Human capital is the engine of organisational growth and a catalyst for economic development for every country. Human resource development has a vital role in stimulating human capital within an organisation (Manresa et al., 2019). Training and development mainly constitute the broader realm of human resource development practices, which is considered the most influential factor in improving employee performance (Mcdowall \& Saunders, 2010). Training and development programs are prominent activities within organisations to make employees competent, boost motivation, retention, awareness from emerging tools and techniques, and market's ebbs and flow. Training is a source of learning; learning is the act of approaching new things which were not explored earlier and enrich existing skills to achieve targeted organisational goals (Luntley, 2008). According to (Aguinis \& Kraiger, 2009), "Training activities can also be beneficial regarding other outcomes at both the individual and team level (e.g., attitudes, motivation, and empowerment)". According to Swanson and Holton (2001) connoted training and development as "a process of systematically developing work-related knowledge and expertise in people for the purpose of improving performance". Besides that, various authors also described the training to acquire and improve skills, knowledge, behaviour, and attitude by employees to perform their assigned work effectively (Goldstein, 1980; Tannenbaum, 1992; Latham, 2011; Noe, 2018). Employees are the backbone of an organisation, and organisational performance depends upon their expertise. Employee performance is not a static phenomenon; instead, it fluctuates by external factors, i.e., training and education. In addition to that, "training may enable consistency in performance across conditions" (Aguinis \& Kraiger, 2009); performance consistency may result in the form of upgrading trainees' self-efficacy or self-management abilities. In * Corresponding author.

E-mail address: arbabkhan954@gmail.com (M. Arwab)

(C) 2022 by the authors; licensee Growing Science, Canada doi: $10.5267 / \mathrm{j} . \mathrm{ms} 1.2021 .10 .004$ 
this regard, human capital theory, developed by Becker (1964), asserts that human resource is the key determinant of socioeconomic development in all perspectives. Furthermore, this theory propounds that education and training are significant instruments to enhance employees' productivity and profitability through imparting required knowledge and skills (Nafukho et al., 2004; Sweetland, 1996). Employee performance considered as a result of an individual's effort towards organisational goals, satisfaction with the job (Hanaysha \& Tahir, 2016), affective commitment (Ocen et al., 2017; Hanaysha \& Tahir, 2016) and reduced turnover intention (Rawashdeh \& Tamimi, 2019). Such factors highly influence the performance of an individual and facilitate them to reach determined goals. Moreover, training transforms employees' behaviour, attitude, and perception from negativity to positivity, which also improves their performance level. This changing behavioural phenomenon enhances employees' energy and involvement level and simultaneously eliminates exhaustion and inefficacy (Macey \& Schneider, 2008; Saks, 2006). Furthermore, engaged employees exert great effort to attain organisational objectives that elevate employees' overall performance (Rubel \& Kee, 2013; Praida \& Sundaray, 2020). Therefore, this paper investigates the influence of training and development on employee performance through different dimensions with special reference to the Indian tourism industry. The tourism industry is associated with the service sector, one of India's largest sectors. According to the World Travel and Tourism Council (WTTC), India placed $10^{\text {th }}$ in terms of GDP. The Indian travel and tourism industry provides $8 \%$ of the total employment of the Indian economy (WTTC, 2020). Moreover, after China, India is the second-largest contributor in generating employment through the tourism sector. The tourism industry is an emerging and growing sector that has a significant contribution to the Indian economy directly or indirectly and provides a huge number of employment. Training and development play a vital role in producing skilled and proficient workforce. Therefore, the foremost aim of the present study is to analyse how training and development influence employee performance by considering different dimensions. Moreover, this study proposes a model in the area of human resource development to be used for testing and improving the performance of employees in the Indian travel and tourism sector.

\section{Literature Review and Hypotheses Development}

\subsection{Training-development}

To deal with globalisation and gain a competitive advantage, Noe and Kodwani (2018) suggested that employees must be well trained, knowledgeable and learn multiple skills. Training and development are components of human resource development that the organization uses as a strategic mechanism to propel the employees towards predetermined goals (Otoo \& Mishra, 2018a). The training program is the key determinant to improve individual and organisational performance (Bell et al., 2017; Khan et al., 2016). These programs positively influence individual performance and play a crucial role in the betterment of team, organization, and society's perspective (Aguinis \& Kraiger, 2009; Salas et al., 2012). In the absence of effective and adequate training, employees could not exert full effort regarding their job expectations (Dhar, 2015) and were unable to achieve desired goals. In this study, training and development were measured through different dimensions, i.e., motivation for training (Bulut \& Culha, 2010; Dias \& Silva, 2016; Bartlett, 2001). These studies mention that employees are motivated to participate in training programs because their motivation encourages them to learn maximum and make training effective. According to Orpen (1999), a high level of motivation towards training enables a positive attitude among trainees and creates a competitive environment within the organisation. Empirical evidence from the studies of Bartlett (2001) and Newman (2011) states that motivation for training is an important precursor to enhance the level of interest in organising training programs within the organisation. The benefits of training are also an essential aspect; according to Dhar (2015), whenever employees perceive that participation in a training program would be beneficial for the organisation and themselves, they show a high level of interest. Bulut and Culha (2010) also endorse that if employees feel that skills and knowledge they have learnt through training would assist them in performing their job, they willingly participate. According to studies conducted by Bartlett (2001) and Dhar (2015), if employees receive support from the organisation, they feel interested in participating in training and exerting likely effort for the success of the organisation.

\subsection{Employee Performance}

Positive execution of an individual in higher productivity and profitability after exerting required effort during the job period considers employee performance (Pradhan \& Jena, 2017). Mathis and Jackson (2009) validated that employee performance consists of work efficiency done, the effectiveness of work done, the quality of work, the quantity of work, and the promptitude of work. Moreover, within an organisation, an individual's cognitive, physical and behavioural efforts to achieve determined goals for organisational success and continuous growth contemplate employee performance (Anitha, 2014; Pradhan \& Jena, 2017). Different elements affect employee's performance, i.e., training programs, supervisor support, organisational support for career development and capacity development programs. However, most organisations organise capacity building/development programs to enhance employees' performance (Ahmad et al., 2015). Employee performance can be improved through exclusive measures that contain job-related skills, knowledge, leading role, promotion, authorization, training and development programs based on skills, evaluation, and reward on their achievements (Wassem et al., 2019). An individual's performance depends on the organisation's policies, practices, design, and features; such factors prompt the employee towards the determined organisation's goals (Anitha, 2014). In the present study, employee's performance was measured through different dimensions, i.e., Task performance, Adaptive performance and Contextual performance, which are taken from the studies of Pradhan and Jena (2017) and Koopmans et al. (2013). According to Borman (1997) and Griffin (2000), task performance is 
the part of individual work performance, and it refers to core technical activities performed by an individual in an organisation. Furthermore, task performance can be differentiated on the basis of behavioural aspects such as work quality, work quantity, job skills and job knowledge. Pradhan and Jena (2017) address the contextual performance as a pro social behaviour of an individual to support in the work environment. Generic instances of contextual performance described by Griffin (2000) such as volunteering for tasks, assisting co-workers and protecting organisations from external elements. Koopmans et al. (2013) and Pradhan and Jena (2017) refer that adaptive performance ensures the ability of an individual to acclimatize effectively with uncertain circumstances in working environment.

\subsection{Training and development to employee performance}

Training and development programs are considered a very influential factor for improving employee's performance and organizational development (Aguinis \& Kraiger, 2009; Otoo \& Mishra, 2018b). Several studies have been carried out to investigate the relationship between training and development and employees performance (Aguinis \& Kraiger, 2009; Bell et al., 2017; Hafeez \& Akbar, 2015; Hanaysha \& Tahir, 2016). It was found that training is a significant instrument to enhance employees' abilities and capabilities. According to human capital theory, companies usually invest in developing the efficiency of employees with the help of training to make them compatible with the market needs (Nafukho et al., 2004). By investing in human resources, companies can reap the benefits at the individual and organisational level in the form of higher productivity and profitability. Moreover, training can update job-related knowledge and skills to handle rapidly changing market demands and emerging technology (Saira et al., 2020). The indictment by Salas et al. (2012) "Training and development activities allow organizations to adapt, compete, excel, innovate, produce, safety, improve service, and reach goals". Overall, training has improved the innovative work behaviour of employees which is helpful to achieve organisational goals (Manresa et al., 2019; Susomrith et al., 2019).

\subsection{Motivation for training and employee performance}

Motivation is an internal force that enables individuals to attain specific goals and objectives (Shahzadi et al., 2014). Motivation for training is the extent in which employees willingly push themselves towards exerting much effort to improve their abilities and efficiency through training to do their tasks effectively (Bulut \& Culha, 2010). The magnitude of learning skills and acquiring knowledge from training programs depend upon how much an employee is motivated to participate in training programs (Ocen \& Francis, 2017). Employees who have great motivation to attend training programs reflect a positive impact on their job performance. According to Newman et al. (2011), employee's performance is highly influenced by motivation for training. Motivation is the key factor in learning unexplored things, obtaining new skills, and enhancing effective performance within an organisation (Uzonna, 2013). Therefore, the following hypotheses have been formulated based on the above discussion:

$\mathbf{H}_{1}$ : There is a significant influence of motivation for training on employee performance.

H1a: There is a significant influence of motivation for training on contextual performance.

$\mathrm{H}_{1 \mathrm{~b}}$ : There is a significant influence of motivation for training on task performance.

$\mathbf{H}_{1 \mathbf{c}}$ : There is a significant influence of motivation for training on adaptive performance.

\subsection{Benefits from training and employee performance}

Human tendency is insatiable; any activity done by humans is for the sake of gaining benefits. The nature of the training program is reciprocal within an organisation. Employees who believe that the training program shall benefit them in enriching their skills and personal development; willingly participate in the training program. Consequently, such training programs yield high performing workforce (Factea et al., 1995; Dhar, 2015). Neo and Wilk (1993) described three different benefits from the training program, i.e., personal, job-related and career benefits. Whenever employees participate in the training program, they are expected to improve their personal growth to improve their capabilities and cultivate their behavior and psychological development. Job-related benefits refer to employee expectations to promote from the existing position and enhance the strong relationship with colleagues and seniors within the organization. Lastly, career-related benefits motivate employees to learn new skills for future perspectives, which are helpful to achieve career objectives (Bulut \& Culha, 2010; Washington et al., 2003; Dhar, 2015). Such factors enhance employees' ability and job performance. Therefore, the following hypotheses have been formulated based on the above discussion:

$\mathbf{H}_{2}$ : There is a significant influence of benefits of training on employee performance.

$\mathbf{H}_{2 \mathbf{a}}$ : There is a significant influence of benefits from training on contextual performance.

$\mathbf{H}_{2 \mathbf{b}}$ : There is a significant influence of benefits from training on task performance.

$\mathbf{H}_{2 \mathbf{c}}$ : There is a significant influence of benefits from training on adaptive performance. 
Firms where employees receive moral and psychological support feel motivated and enhance their performance level to achieve organizational objectives. When organizational support is absent, employees tend to decline their performance graph (Robinson \& Morrison, 1995). To solve work-related problems and upgrading skills, organizational support for training is an essential factor for employees (Dardar et al., 2012). Support for participation in training programs may be vertical or horizontal; vertical support refers to the support from seniors or co-workers, and horizontal support is the extent to which colleagues help each other and solve problems at the same working level (Bulut \& Culha, 2010; Dhar, 2015). Employees perceive that vertical and horizontal support of training programs enhances positive attitudes towards their colleagues and an effective source of improving performance (Bulut \& Culha, 2010). Therefore, the following hypotheses have been formulated based on the above discussion:

$\mathbf{H}_{3}$ : There is a significant influence of support for training on employee performance.

$\mathbf{H}_{3 \mathbf{a}}$ : There is a significant influence of support for training on contextual performance.

$\mathbf{H}_{3 \mathbf{b}}$ : There is a significant influence of support for training on task performance.

$\mathbf{H}_{\mathbf{3}}$ : There is a significant influence of support for training on adaptive performance.

Training and Development Motivation for Training

Motivation for Training

Fig. 1. Hypothesized Model

\section{Methodology}

\subsection{Sample and Data collection}

The sample for this study was contracted from the employees working in selected Indian travel agencies. Researchers approached many travel agencies, but few agencies showed interest to take part in this survey. Data were collected through a well-structured questionnaire using both online and offline survey methods. In the online method, a Google form designed and sent to employees individually and in the offline mode, researchers approached physically to get the responses. The time range of the survey started from mid-January to the first week of March 2021. A total of 225 questionnaires were distributed through both methods; after adjusting, 146 responses were considered for further analysis. A cross-sectional study design was employed for the study.

\subsection{Measures}

All the items used in the measurement scale of this study were extracted from highly cited literature of top-quality journals. A well-structured questionnaire using with the five-point Likert-scale for the data collection, in which " 1 " represents "strongly disagree" to "5" represents "strongly agree".

\section{Training and Development}

"Training and Development" is used as a single term in this study. It was measured from different dimensions such as motivation for training, benefits of training and support for training using with items developed by Bulut and Culha (2010) and Bartlett (2001, 2004). Six items were adopted for motivation for training, five items for benefits for training and four items have been taken for support for training.

\section{Employee performance}

Employee performance was measured through different dimensions, i.e., Task performance, Adaptive performance and contextual performance on a five-point rating scale and adapted from Pradhan and Jena (2017) and Koopmans et al. (2013). A total of 12 items have been taken, 4 each for task performance, contextual performance and adaptive performance.

\section{Findings}

This study was carried-out on middle-level employees of the selected travel agencies in India. A total of 146 responses were extracted for the final study; out of 146 respondents, 69.9 per cent were male while 30.1 per cent were female (mean=1.30, s.d. =.46). As many as 67.8 per cent of respondents come from the $25-34$ age group (mean=1.87, s.d. =.60). A total of 61.6 per cent of the respondents were postgraduate (mean=1.69, s.d. $=.54)$, and 43.2 per cent of respondents held $3-6$ years' work experience $($ mean $=1.89$, s.d. $=.85)$. 
Table 1

Respondent's Profile ( $\mathrm{n}=146)$

\begin{tabular}{|c|c|c|c|c|}
\hline Variable & Sub-Variable & Per cent & Mean & Standard deviation \\
\hline Gender & $\begin{array}{l}\text { Male } \\
\text { Female }\end{array}$ & $\begin{array}{l}69.9 \\
30.1\end{array}$ & 1.3014 & .46043 \\
\hline Age & $\begin{array}{c}\text { Below } 25 \\
25-34 \\
35-44 \\
\text { Above } 44\end{array}$ & $\begin{array}{c}23.3 \\
67.8 \\
6.8 \\
2.1\end{array}$ & 1.8767 & 60902 \\
\hline Qualification & $\begin{array}{c}\text { Graduate } \\
\text { Postgraduate } \\
\text { Others }\end{array}$ & $\begin{array}{c}34.2 \\
61.6 \\
4.2\end{array}$ & 1.6986 & .54292 \\
\hline Work Experience & $\begin{array}{c}\text { 0-02 years } \\
03-06 \text { years } \\
07-10 \text { years } \\
\text { Above } 10 \text { years }\end{array}$ & $\begin{array}{c}36.2 \\
43.2 \\
15.1 \\
5.5\end{array}$ & 1.8973 & .85282 \\
\hline
\end{tabular}

Source: Primary data

Table 2

Correlational Statistics

\begin{tabular}{lllllllll}
\hline & $\boldsymbol{N}$ & Mean & Std. Deviation & $\boldsymbol{M} \_\boldsymbol{T}$ & $\boldsymbol{B} \_\boldsymbol{T}$ & $\boldsymbol{S} \_\boldsymbol{T}$ & $\boldsymbol{T} \_\boldsymbol{P}$ & $\boldsymbol{A} \_\boldsymbol{P}$ \\
\hline M_T & 146 & 3.9195 & .93446 & 1 & & & & \\
B_T & 146 & 3.7425 & .93542 & $.666^{* *}$ & 1 & & \\
S_T & 146 & 3.7233 & .80559 & $.530^{* *}$ & $.634^{* *}$ & 1 & & \\
T_P & 146 & 4.0411 & 1.14877 & $.419^{* *}$ & $.442^{* *}$ & $.445^{* *}$ & 1 & \\
A_P & 146 & 3.9288 & .72578 & $.596^{* *}$ & $.573^{* *}$ & $.592^{* *}$ & $.495^{* *}$ & 1 \\
C_P & 146 & 3.8767 & .76063 & $.575^{* *}$ & $.538^{* *}$ & $.579^{* *}$ & $.511^{* *}$ & $.755^{* *}$ \\
\hline
\end{tabular}

Source: Primary data

$* * p<0.01$

The correlation coefficient is stated, liner relationship among variables (Taylor, 1990). Its recommended rage is +1 to -1 . This study seen to be significant $(p<0.01)$ and positive association among the variable. Moderate coefficient of correlation was seen among the study variables. See Table IV for additional information. Confirmatory Factor Analysis is interdepended technique that is employed to determine factor structure. In the CFA, factor structure is confirmed that is extracted from EFA (Thompson, 2004). Basically, it is the special type of SEM that dealing with measurement models (Brown, 2015).

Table 3

Confirmatory factor Analysis Statistics

\begin{tabular}{|c|c|c|c|c|c|c|c|c|c|}
\hline Label & MFT & BOT & $S F T$ & $A P$ & $C P$ & $T P$ & $A V E$ & $M S V$ & $C R$ \\
\hline MFT5 & 0.777 & & & & & & \multirow{6}{*}{0.617} & \multirow{6}{*}{0.607} & \multirow{6}{*}{0.889} \\
\hline MFT4 & 0.836 & & & & & & & & \\
\hline MFT3 & 0.729 & & & & & & & & \\
\hline MFT2 & 0.788 & & & & & & & & \\
\hline MFT1 & 0.833 & & & & & & & & \\
\hline MFT6 & 0.736 & & & & & & & & \\
\hline BOT6 & & 0.725 & & & & & \multirow{5}{*}{0.681} & \multirow{5}{*}{0.648} & \multirow{5}{*}{0.874} \\
\hline BOT5 & & 0.745 & & & & & & & \\
\hline BOT4 & & 0.771 & & & & & & & \\
\hline BOT3 & & 0.777 & & & & & & & \\
\hline BOT2 & & 0.792 & & & & & & & \\
\hline SFT4 & & & 0.724 & & & & \multirow{4}{*}{0.512} & \multirow{4}{*}{0.448} & \multirow{4}{*}{0.806} \\
\hline SFT3 & & & 0.740 & & & & & & \\
\hline SFT2 & & & 0.773 & & & & & & \\
\hline SFT1 & & & 0.615 & & & & & & \\
\hline AP4 & & & & 0.611 & & & \multirow{4}{*}{0.526} & \multirow{4}{*}{0.424} & \multirow{4}{*}{0.747} \\
\hline AP3 & & & & 0.651 & & & & & \\
\hline AP2 & & & & 0.686 & & & & & \\
\hline AP1 & & & & 0.660 & & & & & \\
\hline CP5 & & & & & 0.711 & & \multirow{4}{*}{0.585} & \multirow{4}{*}{0.424} & \multirow{4}{*}{0.790} \\
\hline $\mathrm{CP} 4$ & & & & & 0.723 & & & & \\
\hline $\mathrm{CP} 3$ & & & & & 0.717 & & & & \\
\hline CP6 & & & & & 0.631 & & & & \\
\hline TP5 & & & & & & 0.651 & \multirow{4}{*}{0.508} & \multirow{4}{*}{0.424} & \multirow{4}{*}{0.696} \\
\hline TP3 & & & & & & 0.601 & & & \\
\hline TP2 & & & & & & 0.672 & & & \\
\hline TP1 & & & & & & 0.629 & & & \\
\hline
\end{tabular}

Source: Primary data 
CFA was performed using AMOS 20.0 version to justify the factor structure and validation of scale (Brown, 2015). Conceptually, CFA was performed to check two types of validity; convergent and discriminant validity. The convergent validity establishes how closely several ways of estimating a construct yield expected results. The convergent validity assessed through the Average Variance Extracted is determined the same as the mean variance extracted for the loading on the construct; the AVE should be more than 0.5 . Another determinant considers composite reliability (CR), that is calculated with the square of sum of the loadings for each latent variable and sum of the error variance which terms for a construct (Fornell \& Larcker, 1981; Hair et al., 1998). The threshold limit of the CR should be higher than 0.7 (Cronbach, 1951; Field, 2005; Hair, 2011; N. K. Malhotra, 2004). Finally, the value of composite reliability (CR) seems to be more than the benchmark. Hence, all the aforementioned criteria of convergent validity are satisfactory. Nonetheless, the discriminant validity was assessed through, average variance extracted (AVE) which should be more than maximum shared variance (MSV), therefore in the present study, the values for AVE noted to be greater than MSV for all the latent variables. With a factor correlation of more than 0.6, each construct was found to be more closely and strongly associated to its measurement and other constructs in the study (Brown, 2015). Additionally, for each construct, the square root of AVE is found to be more than its co-relational value. The measuring model is used to assess the reliability and validity of the studies constructed qualitatively (Henseler et al., 2009). The early CFA findings demonstrated that the model was a good fit by way of the following indices.

Table 4

SEM Fit Indices

\begin{tabular}{cccc}
\hline Fit Indices & Cut off Values & Model Study & References \\
\hline Absolute Fit Measure & $1-3$ & & Byrne (1994); Raykov \& Marcoulides (2000); \\
CMIN/DF & $<0.05,<0.08$ & 0.015 & Tabachnic \& Fidell (2007); \\
RMR & $<0.05,<0.08$ & 0.09 & \\
RMSEA & $>0.90$ & 0.820 \\
Incremental Fit Measure & $>0.90$ & 0.811 \\
CFI & $>0.90$ & 0.863 \\
TLI & $>0.90$ & 0.815 \\
GFI & $>0.90$ & 0.823 \\
\hline NFI & & \\
\hline IFI & & \\
\hline Source: Primary & & \\
\hline
\end{tabular}

Source: Primary data

CFA statistics produces several indices. The amount of observed and expected covariance matrices was revealed using Chisquare $(\mathrm{CMIN} / \mathrm{DF}=2.164)$. The incremental fit measure was assess using $\mathrm{CFI}=.820, \mathrm{GFI}=.868, \mathrm{TLI}=.811, \mathrm{NFI}=.815$ the recommended value of such indices should be more than 0.90 , but some more than 0.80 is also acceptable (Benson $\&$ Fleishman, 1994; Curran, West \& Finch, 1996; Moutinho \& Hutcheson, 2014; Ansari \& Khan, 2020).

\section{Hypotheses testing}

Figure 2 shows the path coefficient, which shows how one hypothesis is linked to the others. Surprisingly, six out of nine hypotheses were found to be supported, with $85.8 \%$ variance explained in task performance, 71.8 percent variance explained in contextual performance, and 75.1 percent variance explained in adaptive performance. Significant influence of motivation for training was seen on contextual performance $(\beta=0.277, p<0.001, \mathrm{CR}=3.86, \mathrm{SE}=0.075)$, meaning thereby that motivation for training directly influencing contextual performance. Similarly, a direct impact was seen between motivation for training and contextual performance $(\beta=0.373, p<0.001, \mathrm{CR}=4.877, \mathrm{SE}=.076)$. Additionally, motivation for training has a significant impact on adaptive performance $(\beta=.37, p<0.001, \mathrm{CR}=4.78, \mathrm{SE}=.077)$, meaning thereby there is a direct effect of motivation for training on adaptive performance. Although, there is an insignificant influence of benefits for training was seen on task performance $(\beta=-.034, p>0.001, \mathrm{CR}=-.601, \mathrm{SE}=.057)$.

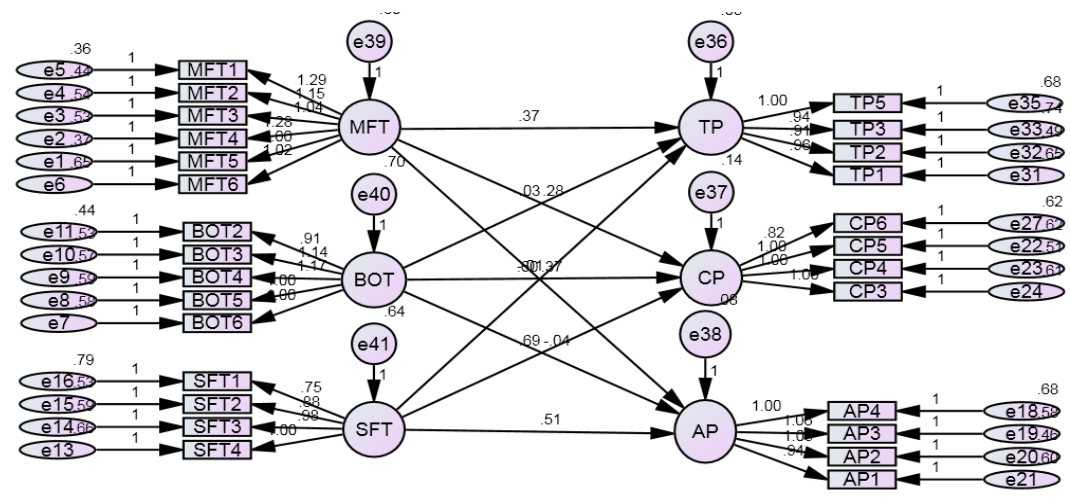

Fig. 2 Path Analysis 
Similarly, benefits for training have an insignificant impact on contextual performance $(\beta=.-.011, p>0.001, \mathrm{CR}=-.168, \mathrm{SE}$ $=.065)$. In addition to this, the benefit for training was seen to be insignificantly influencing adaptive performance among the students $(\beta=-.039, p>0.001, \mathrm{CR}=-.705, \mathrm{SE}=.055)$.

Table 5

Summarized hypotheses

\begin{tabular}{|c|c|c|c|c|c|c|c|}
\hline Variable & & & Estimate & $S E$ & $C R$ & $P$ & Decision? \\
\hline $\mathrm{CP}$ & $\leftarrow$ & MFT & 0.277 & 0.075 & 3.68 & $* * *$ & Significant \\
\hline TP & $\leftarrow$ & MFT & 0.373 & 0.076 & 4.877 & $* * *$ & Significant \\
\hline AP & $\leftarrow$ & MFT & 0.37 & 0.077 & 4.785 & $* * *$ & Significant \\
\hline $\mathrm{CP}$ & $\leftarrow$ & BOT & -0.011 & 0.065 & -0.168 & 0.867 & Insignificant \\
\hline TP & $\leftarrow$ & BOT & -0.034 & 0.057 & -0.601 & 0.548 & Insignificant \\
\hline AP & $\leftarrow$ & BOT & -0.039 & 0.055 & -0.705 & 0.481 & Insignificant \\
\hline $\mathrm{CP}$ & $\leftarrow$ & SFT & 0.694 & 0.112 & 6.221 & $* * *$ & Significant \\
\hline TP & $\leftarrow$ & SFT & 0.596 & 0.103 & 5.804 & $* * *$ & Significant \\
\hline AP & $\leftarrow$ & SFT & 0.507 & 0.095 & 5.311 & $* * *$ & Significant \\
\hline
\end{tabular}

Source: Primary data

Interestingly, supports for training seen to be a significant influence on adaptive performance $(\beta=.507, p<0.001, \mathrm{CR}=5.311$, $\mathrm{SE}=.095)$, meaning thereby that a 1 unit increase in support for training enhances .507 unit increase in an adaptive performance. Additionally, a significant relationship was seen between supports for training and contextual performance $(\beta=.694$, $p<0.001, \mathrm{CR}=6.22, \mathrm{SE}=.112)$. Lastly, supports for training significantly influence task performance $(\beta=.596, p<0.001$, $\mathrm{CR}=5.804, \mathrm{SE}=.103$ ) refers that a 1 unit increase in supports for training enhances a .596 unit increase in task performance among employees.

\section{Discussions and conclusion}

The prime motive of this study was to assess the influence of training and development on employee's performance in the context of the Indian tourism industry. The majority of the employees, who participated in the survey, are male (69.9\%) and predominantly come from the 25-35 age group (67.8\%). 61.6 percent of employees possess a postgraduate degree with 3-6 years of work experience (43.2\%). Training and development were used as one and a whole independent variable in the present study and were measured through three dimensions motivation for training, benefits of training and support for training. These measures are in continuation with Bulut and Culha (2010), Dias and Silva (2016), Bartlett (2001). Its influence was measured on employee performance through three dimensions Task performance, Adaptive performance and contextual performance. The measures of employee performance are in continuation with Pradhan (2017) and Koopmans (2013). It is evident from the results that out of the nine hypotheses, six hypotheses supported the evidence, while three hypotheses were found not to be supported. A significant and positive influence was found of contextual performance, task performance and adaptive performance on motivation for training and support for training, while an insignificant influence was reported of contextual performance, task performance and adaptive performance on benefits of training. The findings of this study demonstrate that employee participation in training and development activities increased their performance. The outcomes are in continuation with the principles of Cole (2002). Training and development (independent variable) were computed with employee performance (dependent variable), and the relationship was found positively correlated and statistically significant. The findings of the study confirm that training and development have a significant and positive influence on employee performance and are extremely important for employee's overall development and organization's growth. Human capital is the most valuable asset for any organisation; thus, investing in training and development always leads to higher and long-term returns in terms of profitability, sustainability, development and growth. The performance of an employee is influenced by factors such as knowledge, skill, and abilities. Training and development fill this gap by providing the required knowledge, skill and abilities to perform the job. In the tourism industry, which is one of the key sources for the economic growth of a nation (Cravo, 2010; Cunningham, 2011), employees' performance can be improved through training and development (Chi, Wu \& Lin, 2008; Yi-Chun \& Jacobs, 2008). In this regard, researchers have tested that training and development influence employee performance. Employees would yield benefit to participating with training and development programs since it would also help them to advance in their life-long careers and avail a supreme position within the firm. As a result, the efficiency of the organisation would improve. Employees are the asset of an organization; if they are skilled and trained (Tahir et al., 2014), they will outperform those who are unskilled and untrained. Therefore, the aim of this study was to validate the relationship between training-development and employee performance.

\section{Theoretical and practical implications}

The most successful method of motivating and retaining human resources within a business is through training and development. Importantly, training has been identified as a critical component of the bundles of practises that have emerged from research on high-performance work systems. In conclusion, this study explored the influence of training-development on employee performance in the context of the Indian tourism industry. This study has advanced the literature on employee 
performance in the Indian tourism industry by assessing the significance of various dimensions of training and development discussed in the study. Business organisations, marketers and industry practitioners have been spending a lot of money on training their employees' abilities. Thus, the findings of this study would be fruitful for them in designing appropriate training programs for enhancing employee performance. Because better employee performance leads to organisational growth and development in terms of profitability, sustainability and goodwill. The organisations that can learn faster than their competitors will be the winners in the twenty-first century. Thus, on the basis of the findings of this study better and improved training initiatives and quality programs could be formulated by the concerned organisations to gain the competitive advantage over their counterparts.

\section{Limitations and future research directions}

Similar to other studies, present study also has multiple limitations. First, this study is based on survey and cross-sectional in nature. Therefore, it is difficult to determine whether the connections discovered among the various components are causal. As a result, it is suggested that future studies could be experimental and longitudinal to conclusively establish the correlations discovered in this study. Second, India is a collectivist country with distinct cultural beliefs, unlike western countries (Dhar, 2012; Paul, Roy \& Mukhopadhyay, 2006; Tu, Lin \& Chang, 2011). Therefore, the cultural aspect should be given consideration in future studies while assessing employee performance. Third, due to time constraints the sample chosen for the study was small. Future researchers could adopt a large sample size for better results. Fourth, the survey respondents were employees working in travel agencies. Therefore, the findings of this study cannot be generalised to other industries. For generalising the findings, future researchers should collect data from various organisations, including MNCs, airlines, banks and contact centres. Finally, this study's findings were based on a survey method. As a result, future research could be using a qualitative approach to gain a more in-depth understanding of the elements analysed in present study.

\section{References}

Aguinis, H., \& Kraiger, K. (2009). Benefits of training and development for individuals and teams, organizations, and society. Annual Review of Psychology, 60, 451-474. https://doi.org/10.1146/annurev.psych.60.110707.163505

Ahmad, T., Farrukh, F., \& Nazir, S. (2015). Capacity building boost employee's performance. Industrial and Commercial Training, 47(2), 61-66. https://doi.org/10.1108/ICT-05-2014-0036

Albrecht, S. L., \& Marty, A. (2020). Personality, self-efficacy and job resources and their associations with employee engagement, affective commitment and turnover intentions. International Journal of Human Resource Management, 31(5), 657681. https://doi.org/10.1080/09585192.2017.1362660

Anitha, J. (2014). Determinants of employee engagement and their impact on employee performance. International Journal of Productivity and Performance Management, 63(3), 308-323. https://doi.org/10.1108/IJPPM-01-2013-0008

Ansari, J. A. N., \& Khan, N. A. (2020). Exploring the role of social media in collaborative learning the new domain of learning. Smart Learning Environments, 7(1), 1-16.

Arbuckle, J. (2008). Amos 17.0 user's guide. SPSS Inc..

Bagozzi, R. P., \& Yi, Y. (1988). On the evaluation of structural equation models. Journal of the academy of marketing science, 16(1), 74-94.

Bakker, A. B., \& Demerouti, E. (2008). Towards a model of work engagement. Career Development International, 13(3), 209-223. https://doi.org/10.1108/13620430810870476

Bartlett, K. R. (2001). The relationship between training and organizational commitment: A study in the health care field. Human Resource Development Quarterly, 12(4), 335-352.

Bedarkar, M., \& Pandita, D. (2014). A study on the drivers of employee engagement impacting employee performance. Procedia - Social and Behavioral Sciences, 133, 106-115. https://doi.org/10.1016/j.sbspro.2014.04.174

Bell, B. S., Tannenbaum, S. I., Kevin Ford, J., Noe, R. A., \& Kraiger, K. (2017). 100 years of training and development research: What we know and where we should go. Journal of Applied Psychology, 102(3), 305-323. https://doi.org/10.1037/ap10000142.

Benson, J., \& Fleishman, J. A. (1994). The robustness of maximum likelihood and distribution-free estimators to non-normality in confirmatory factor analysis. Quality and Quantity, 28(2), 117-136.

Borman, W. C., \& Motowidlo, S. J. (1997). Task performance and contextual performance: The meaning for personnel selection research. Human performance, 10(2), 99-109.

Brown, T. A. (2015). Confirmatory factor analysis for applied research. Guilford publications.

Bulut, C., \& Culha, O. (2010). The effects of organizational training on organizational commitment. International Journal of Training and Development, 14(4), 309-322.

Chi, N. W., Wu, C. Y., \& Lin, C. Y. Y. (2008). Does training facilitate SME's performance? International Journal of Human Resource Management, 19(10), 1962-1975

Chung, N. G., \& Angeline, T. (2010). Does work engagement mediate the relationship between job resources and job performance of employees? African Journal of Business Management, 4(9), 1837-1843.

Cole, G.A. (2002) Personnel and Human Resource Management. 5th Edition, York Publishers, Continuum London

Cravo, T. A. (2010). SMEs and economic growth in the Brazilian micro-regions. Papers in Regional Science, 89(4), 711-734

Cronbach, L. J. (1951). Coefficient alpha and the internal structure of tests. psychometrika, 16(3), 297-334. 
Cunningham, L. X. (2011). SMEs as motor of growth: a review of China's SMEs development in thirty years (1978-2008). Human Systems Management, 30(1), 39-54.

Curran, P. J., West, S. G., \& Finch, J. F. (1996). The robustness of test statistics to nonnormality and specification error in confirmatory factor analysis. Psychological methods, $1(1), 16$.

Dardar, A. H. A., Jusoh, A., \& Rasli, A. (2012). The impact of job training, job satisfaction and alternative job opportunities on job turnover in Libyan oil companies. Procedia-Social and Behavioral Sciences, 40, 389-394.

De Saá-Pérez, P., Díaz-Díaz, N. L., \& Ballesteros-Rodríguez, J. L. (2012). The role of training to innovate in SMEs. Innovation: Management, Policy and Practice, 14(2), 218-230. https://doi.org/10.5172/impp.2012.14.2.218

Dardar, A. H. A., Jusoh, A., \& Rasli, A. (2012). The impact of job training, job satisfaction and alternative job opportunities on job turnover in Libyan oil companies. Procedia-Social and Behavioral Sciences, 40, 389-394.

Dhar, R. L. (2015). Service quality and the training of employees: The mediating role of organizational commitment. Tourism Management, 46, 419-430.

Dias, Á., \& Silva, R. (2016). Organizational training and organizational commitment: a literature review and conceptual development. International Journal of Innovative Science, Engineering \& Technology, 3(1), 387-399.

Egan, T. M., Yang, B., \& Bartlett, K. R. (2004). The effects of organizational learning culture and job satisfaction on motivation to transfer learning and turnover intention. Human resource development quarterly, 15(3), 279-301.

Facteau, J. D., Dobbins, G. H., Russell, J. E. A., Ladd, R. T., \& Kudisch, J. D. (1995). The influence of general perceptions of the training environment on pre-training motivation and perceived training transfer. Journal of Management.

Field, A. (2005). Factor analysis using SPSS. Retrieved March, 17(2019), 63-71.

Fornell, C., \& Larcker, D. F. (1981). Structural equation models with unobservable variables and measurement error: Algebra and statistics.

Goldstein, I. L. (1980). Training in work organizations. Annual Review of Psychology, 31(1), 229-272.

Griffin, M., Neal, A., \& Neale, M. (2000). The contribution of task performance and contextual performance to effectiveness: Investigating the role of situational constraints. Applied Psychology, 49(3), 517-533.

Hafeez, U., \& Akbar, W. (2015). Impact of training on employees performance: Evidence from pharmaceutical companies in Karachi, Pakistan. Business Management and Strategy, 6(1), 49. https://doi.org/10.5296/bms.v6i1.7804

Hair, J. F. Jr., Anderson, R., Tatham, R., \& W. C. (1998) Multivariate Data Analysis (5th ed.). Upper Saddle River, NJ: Prentice Hall

Hair, J. F. (2009). Multivariate data analysis

Hair, J. F. (2011). Multivariate data analysis: An overview. International Encyclopedia of Statistical Science, 904907. https://doi.org/10.1007/978-3-642-04898-2 395

Hanaysha, J., \& Tahir, P. R. (2016). Examining the effects of employee empowerment, teamwork, and employee training on job satisfaction. Procedia - Social and Behavioral Sciences, 219, 272-282. https://doi.org/10.1016/j.sbspro.2016.05.016

Harrington, D. (2009). Confirmatory factor analysis. Oxford university press.

Henseler, J., Ringle, C. M., \& Sinkovics, R. R. (2009). The use of partial least squares path modeling in international marketing. In New challenges to international marketing. Emerald Group Publishing Limited.

Islam, O. N. J. U. (2017). Enhancing organizational commitment and employee performance through employee engagement: an empirical check. Studies, 8(2), 146-165.

Johnson, K. R., Park, S., \& Bartlett, K. R. (2018). Perceptions of customer service orientation, training, and employee engagement in Jamaica's hospitality sector. European Journal of Training and Development, 42(3-4), 191-209. https://doi.org/10.1108/EJTD-11-2017-0094

Kahn, W. A. (1990). Psychological conditions of personal engagement and disengagement at work. Physical Review B, 36(5), 2607-2613. https://doi.org/10.1103/PhysRevB.36.2607

Karatepe, O. M. (2013). High-performance work practices and hotel employee performance: The mediation of work engagement. International Journal of Hospitality Management, 32(1), 132-140. https://doi.org/10.1016/j.ijhm.2012.05.003

Kerdpitak, C., \& Jermsittiparsert, K. (2020). The impact of human resource management practices on competitive advantage: Mediating role of employee engagement in Thailand. Systematic Reviews in Pharmacy, 11(1), $443-452$. https://doi.org/10.5530/srp.2020.1.56

Khan, A. A., Abbasi, S. O. B. H., Waseem, R. M., Ayaz, M., \& Ijaz, M. (2016). Impact of training and development of employees on employee performance through job satisfaction: A study of telecom sector of Pakistan. Business Management and Strategy, 7(1), 29. https://doi.org/10.5296/bms.v7i1.9024

Koopmans, L., Bernaards, C., Hildebrandt, V., Van Buuren, S., Van der Beek, A. J., \& de Vet, H. C. (2013). Development of an individual work performance questionnaire. International journal of productivity and Performance Management.

Latham, G. P. (2011). Human resource training and development. In M. F. R. Kets de Vries \& K. Korotov (Eds.), The international library of critical writings on business and management. Leadership development (p. 3-40). Edward Elgar Publishing.

Luntley, M. (2008). Training and learning. Educational Philosophy and Theory, 40(5), 695-711. https://doi.org/10.1111/j.1469-5812.2008.00463.x

Macey, W. H., \& Schneider, B. (2008). The meaning of employee engagement. Industrial and Organizational Psychology, 1(1), 3-30. https://doi.org/10.1111/j.1754-9434.2007.0002.x

Macey, W. H., Schneider, B., Barbera, K. M., \& Young, S. A. (2011). Employee engagement: Tools for analysis, practice, and competitive advantage (Vol. 31). John Wiley \& Sons. 
Malhotra, N. K., Hall, J., Shaw, M., \& Oppenheim, P. (2004). Essentials of marketing research: an applied orientation. Pearson Education Australia.

Manresa, A., Bikfalvi, A., \& Simon, A. (2019). The impact of training and development practices on innovation and financial performance. Industrial and Commercial Training, 51(7-8), 421-444. https://doi.org/10.1108/ICT-04-2019-0035

Mathis, R.L. and Jackson, J.H. (2009), Human Resource Management, South-Western Cengage Learning, Mason, OH.

Moutinho, L., \& Hutcheson, G. (2014). Generalised linear models (GLM) in marketing.

Mcdowall, A., \& Saunders, M. N. K. (2010). UK managers' conceptions of employee training and development, 34(7), 609630. https://doi.org/10.1108/03090591011070752

Memon, M. A., Salleh, R., Nordin, S. M., Cheah, J. H., Ting, H., \& Chuah, F. (2018). Person-organisation fit and turnover intention: The mediating role of work engagement. Journal of Management Development, 37(3), $285-298$. https://doi.org/10.1108/JMD-07-2017-0232

Menguc, B., Auh, S., Fisher, M., \& Haddad, A. (2013). To be engaged or not to be engaged: The antecedents and consequences of service employee engagement. Journal of Business Research, 66(11), $2163-2170$. https://doi.org/10.1016/j.jbusres.2012.01.007

Nafukho, F. M., Hairston, N. R., \& Brooks, K. (2004). Human capital theory: Implications for human resource development. Human Resource Development International, 7(4), 545-551. https://doi.org/10.1080/1367886042000299843

Newman, A., Thanacoody, R., \& Hui, W. (2011). The impact of employee perceptions of training on organizational commitment and turnover intentions: A study of multinationals in the Chinese service sector. The International Journal of Human Resource Management, 22(8), 1765-1787.

Noe, R. A., \& Kodwani, A. D. (2018). Employee training and development, 7e. McGraw-Hill Education. Science, Engineering \& Technology, 3(1), 387-399.

Noe, R. A., \& Wilk, S. L. (1993). Investigation of the factors that influence employees' participation in development activities. Journal of Applied Psychology, 78(2), 291.

Ocen, E., Francis, K., \& Angundaru, G. (2017). The role of training in building employee commitment: the mediating effect of job satisfaction. European Journal of Training and Development, 41(9), 742-757.

Orpen, C. (1999). The impact of self-efficacy on the effectiveness of employee training. Journal of Workplace Learning.

Otoo, F. N. K., \& Mishra, M. (2018a). Influence of human resource development (HRD) practices on hotel industry's performance: The role of employee competencies. European Journal of Training and Development, 42(7-8), 435-454. https://doi.org/10.1108/EJTD-12-2017-0113

Paul, P., Roy, A., \& Mukhopadhyay, K. (2006). The impact of cultural values on marketing ethical norms: A study in India and the United States. Journal of International Marketing, 14(4), 28-56

Pradhan, R. K., \& Jena, L. K. (2017). Employee performance at workplace: Conceptual model and empirical validation. Business Perspectives and Research, 5(1), 69-85. https://doi.org/10.1177/2278533716671630

Praida, P. K., \& Sundaray, B. K. (2020). Training and employee engagement: An impact analysis. Journal of University of Shanghai for Science and Technology, 22(11), 302-317.

Rawashdeh, A. M., \& Tamimi, S. A. (2019). The impact of employee perceptions of training on organizational commitment and turnover intention: An empirical study of nurses in Jordanian hospitals. European Journal of Training and Development, 44(2-3), 191-207. https://doi.org/10.1108/EJTD-07-2019-0112

Raykov \& Marcoulides Byrne, B. M. (1994). Structural equation modeling with EQS and EQS/Windows: Basic concepts, applications, and programming. Sage.

Raykov, T., \& Marcoulides, G. A. (2000). A method for comparing completely standardized solutions in multiple groups. Structural equation modeling, 7(2), 292-308.

Robinson, S. L., \& Morrison, E.W. (1995). Psychological contracts and OCB: The effect of unfulfilled obligations on civic virtue behavior. Journal of Organizational Behavior, 16(3), 289e298.

Rubel, M. R. B., \& Kee, D. M. H. (2013). Perceived support and employee performance: The mediating role of employee engagement. Life Science Journal, 10(4), 2557-2567.

Saira, S., Mansoor, S., Ishaque, S., Ehtisham, S., \& Ali, M. (2020). Training effectiveness and employee outcomes: a study of an Australian manufacturing organization. European Journal of Training and Development.

Saks, A. M. (2006). Antecedents and consequences of employee engagement. Journal of Managerial Psychology, 21(7), 600619. https://doi.org/10.1108/02683940610690169

Salas, E., Tannenbaum, S. I., Kraiger, K., \& Smith-Jentsch, K. A. (2012). The science of training and development in organizations: What matters in practice. Psychological Science in the Public Interest, Supplement, 13(2), 74-101. https://doi.org/10.1177/1529100612436661

Sattar, T., Ahmad, K., \& Hassan, S. M. (2015). Role of human resource practices in employee performance and job satisfaction with mediating effect of employee engagement. Pakistan Economic and Social Review, 81-96.

Schumacker, R. E., \& Lomax, R. G. (2004). A beginner's guide to structural equation modeling. psychology press.

Shahzadi, I., Javed, A., Pirzada, S. S., Nasreen, S., \& Khanam, F. (2014). Impact of employee motivation on employee performance. European Journal of Business and Management, 6(23), 159-166.

Sivapragasam, P., \& Raya, R. P. (2018). HRM and employee engagement link: Mediating role of employee well-being. Global Business Review, 19(1), 147-161. https://doi.org/10.1177/0972150917713369

Solomon Markos, M. S. S. (2010). Employee engagement: The key to improving performance. International Journal of Management, 11(4), 108-126. https://doi.org/10.34218/IJM.11.4.2020.013 
Sugianingrat, I. A. P. W., Widyawati, S. R., da Costa, C. A. D. J., Ximenes, M., Piedade, S. $\quad$ D. R., \& Sarmawa, W. G. (2019). The employee engagement and OCB as mediating on employee performance. International Journal of Productivity and Performance Management, 68(2), 319-339.

Susomrith, P., Coetzer, A., \& Ampofo, E. (2019). Training and development in small professional services firms. European Journal of Training and Development, 43(5-6), 517-535. https://doi.org/10.1108/EJTD-11-2018-0113

Swanson, R. A., Holton, E., \& Holton, E. F. (2001). Foundations of human resource development. Berrett-Koehler Publishers.

Sweetland, S. R. (1996). Human capital theory: Foundations of a field of inquiry. Review of Educational Research, 66(3), 341-359. https://doi.org/10.3102/00346543066003341

Tabachnick, B. G., Fidell, L. S., \& Ullman, J. B. (2007). Using multivariate statistics (Vol. 5, pp. 481-498). Boston, MA: Pearson.

Tahir, N., Yousafzai, I. K., Jan, S., \& Hashim, M. (2014). The impact of training and development on employees performance and productivity: A case study of United Bank Limited Peshawar City, KPK, Pakistan. International Journal of Academic Research in Business and Social Sciences, 4(4), 86.

Taylor, R. (1990). Interpretation of the correlation coefficient: a basic review. Journal of diagnostic medical sonography, 6(1), 35-39.

Tannenbaum, S. I., \& Yukl, G. (1992). Training and development in work organizations. Annual Review of Psychology, 43(1), 399-441.

Thompson, B. (2004). Exploratory and confirmatory factor analysis: Understanding concepts and applications. https://doi.org/10.1037/10694-000

Tu, Y.-T., Lin, S.-Y., \& Chang, Y.-Y. (2011). A cross-cultural comparison by individualism/collectivism among Brazil, Russia, India and China.International Business Research, 4(2), 175-182

Uzonna, U. R. (2013). Impact of motivation on employees performance: A case study of Credit West Bank Cyprus. Journal of Economics and International Finance, 5(5), 199-211.

Washington, K., Feinstein, A. H. and Busser, J. A. (2003). Evaluating the effect of training on perceptions of internal occupational status. International Journal of Hospitality Management, 22, 3, 243-65.

Wassem, M., Baig, S. A., Abrar, M., Hashim, M., Zia-Ur-Rehman, M., Awan, U., Amjad, F., \& Nawab, Y. (2019). Impact of capacity building and managerial support on employees' performance: The moderating role of employees' retention. $S A G E$ Open, 9(3). https://doi.org/10.1177/2158244019859957

WTTC releases its annual travel and tourism economic impact 2020. (2020, September 26). Skyview Patnitop. https://skyviewpatnitop.com/blogs/wttc-annual-travel-tourism-economic-impact-2020/

Yi-Chun, L., \& Jacobs, R. L. (2008). The perceptions of human resource development professionals in Taiwan regarding their working relationships with subject matter experts (SMEs) during the training design process. Human Resource Development International, 11(3), $237 \mathrm{e} 252$. 
(C) 2022 by the authors; licensee Growing Science, Canada. This is an open access article distributed under the terms and conditions of the Creative Commons Attribution (CC-BY) license (http://creativecommons.org/licenses/by/4.0/). 